\title{
PEMBELAJARAN TOUR GUIDING: DESKRIPSI CERITA OGOH-OGOH BERBAHASA INGGRIS SEBAGAI DAYA TARIK PARIWISATA BUDAYA
}

\author{
Md. Yudyantara Risadi
}

${ }^{l}$ Universitas Hindu Negeri I Gusti Bagus Sugriwa, Denpasar, Indonesia, yudyantara@uhnsugriwa.ac.id:

\begin{abstract}
ABSTRAK
Tour guide merupakan salah satu mata pelajaran yang sering diberikan kepada mahasiswa yang mengambil jurusan pariwisata. Mata pelajaran ini memberikan wawasan untuk dapat menjadi pramuwisata yang baik dan menjadi garda terdepan dalam pengembangan pariwisata yang baik. Menjadi pramuwisata harus memiliki wawasan yang luas dalam sektor pariwisata salah satunya pariwisata budaya. Pariwisata budaya dapat ditemukan di banyak belahan dunia, khususnya Bali yang memiliki banyak budaya di daerahnya masing-masing, seperti ogoh-ogoh yang menjadi destinasi tontonan menarik bagi wisatawan domestik dan mancanegara. Penelitian ini bertujuan untuk menemukan teknik mengajar dalam mata pelajaran tour guide materi "Pendeskripsian cerita ogoh-ogoh" dengan tahapan pengajaran yang tepat. Metode yang digunakan adalah metode kualitatif dengan teknik pengumpulan data melalui observasi, wawancara, dan dokumentasi serta didukung dengan penelitian kepustakaan. Dalam menentukan informan atau narasumber, teknik purposive sampling digunakan. Kajian ini akan membantu para pengajar untuk dapat menemukan cara membuat materi serta cara mengajarkan materi tersebut kepada para siswanya.

Berdasarkan hasil dari penelitian di atas, dapat disimpulkan bahwa pendeskripsian ogoh-ogoh mampu didapatkan dengan cara mencari para arsitek ogoh-ogoh tersebut dengan mewawancarai mereka. Pendeskripsian ogoh-ogoh pun didapatkan dengan melakukan wawancara mendalam dan dokumentasi dari para arsitek tersebut. Dilanjutkan dengan memberikan tahapan mengajar yang didapatkan dengan wawancara serta penelitian kepustakaan. Didapatkan bawah teknik mengajar yang tepat adalah menggunakan teknik bercerita (story telling). Adapun tahapan mengajar dalam bercerita ini menjadi 5 tahapan, 1) berfokus pada pencarian cerita ogoh-ogoh (materi), 2) berfokus pada kesiapan para siswa dengan memberikan pancingan yang terkait dengan materi, 3) memberikan gambaran kepada para siswa tentang cerita ogoh-ogoh tersebut dan meminta mereka berlatih dengan ekspresi mereka sendiri dalam bercerita, 4) berfokus pada bagaimana cara mereka menjadi pramuwisata dan bercerita mengenai cerita ogoh-ogoh tersebut, dan 5) hanya berfokus pada pemberian umpan balik dengan tujuan menambah pengetahuan yang mereka dapat sebelumnya.
\end{abstract}

Kata Kunci: Bercerita, Guiding, Ogoh-Ogoh, Pariwisata, Pramuwisata 
TOUR GUIDING: DESCRIPTION OF “OGOH-OGOH” STORY IN ENGLISH AS CULTURAL TOURISM ATTRACTION

\begin{abstract}
Tour guiding is one of the school subjects' to be taught in school, especially for students who enroll in tourism school. This subject gives knowledge to be a good tour guide and be the leader of the improvement of good tourism aspect in a country. To be a good tour guide, it is a must to have knowledge in every aspect of tourism, one of them is cultural tourism. Cultural tourism can be seen in many countries, especially Bali (one of the destination places in Indonesia) that has many cultures within it, such as ogoh-ogoh that become one attraction for domestic and non-domestic tourists. This study aims at finding the appropriate technique of teaching in tour guiding subject with item "Description of ogoh-ogoh's story". The method of this research is qualitative method with observation, interview, and documentation as the data collection and library research as the supporting data to complete the primary data. The informants used in this research were purposively determined. This study is able to help teachers to find out how they teach the students with appropriate technique.

Based on the findings, it can be concluded that the description of ogoh-ogoh's story can be found properly by interviewing the architects of the ogoh-ogoh in order to find out the sotry in more details. The theme of ogoh-ogoh's story can be in many forms, such as evil, monster, or sometimes God (its manifestation) againsts evil or demons. After finding how to get the story in details, then these stories must be delivered in the classroom in a specific technique, one of the techniques that can be used in the classroom is story telling. This technique is appropriate because it gives a natural way to deliver the story and the information can be interactively received by tourists. This technique has 5 stages, 1) focusing on finding the story of ogoh-ogoh (item of teaching), 2) focusing on the readiness of the students, 3) giving background knowledge to the students and asking them to read the story with their own expression, 4) focusing on how they students become the tour guide telling the story of ogoh-ogoh with their own expression, and 5) focusing on giving feedbacks in order to give additional knowledge to the students.
\end{abstract}

Keywords : Guiding, Ogoh-Ogoh, Story Telling, Tour Guide, Tourism

Copyright ${ }^{2} 2021$. UHN IGB Sugriwa Denpasar. All Right Reserved 


\section{PENDAHULUAN}

Pembelajaran bahasa Inggris merupakan suatu unsur penting dalam pengembangan sumber daya manusia dalam suatu negara untuk berbagai sektor. Salah satu sektor yang sangat bergantung dengan bahasa Inggris adalah sektor pariwisata. Hal ini disebabkan karena bahasa Inggris memiliki fungsinya sendiri sebagai bahasa internasional yang digunakan untuk dapat berkomunikasi di berbagai negara dan berbagai sektor khususnya sektor pariwisata itu sendiri (Pebriana, Mulyawan, \& Sutrisno, 2021). Cara atau pemberian materi bahasa Inggris dalam ranah pariwisata pun beragam, Susila, Sudarmawan, dan Purandina, (2019) memberikan pendapat bahwa salah satu cara mengajar bahasa Inggris dapat berupa dengan memberikan tour guiding yang tentunya sangat berguna jika dikaitkan dengan sektor pariwisata dikarenakan tour guiding merupakan salat satu penggerak atau faktor penting baik atau buruknya pariwisata di suatu daerah tersebut atau dengan kata lain kemampuan seorang pramuwisata (tour guide) berbanding lurus dengan tingkat kepuasan pengalaman yang didapat oleh wisatawan. Keberadaan tour guide ini adalah untuk menjadi penghubung antara wisatawan dengan pusat ikon destinasi serta budaya lokal karena dalam konteks pariwisata, pramuwisata merupakan penerjemah, wartawan, guru, pemimpin, informan, juru terang, humas, pemandu, pendamping, penghibur, pekerja budaya, seniman bahkan sebagai motivator (Susila, Sudarmawan, \& Purandina, 2019).

Berkaitan dengan hal di atas, Bali merupakan salah satu destinasi pariwisata yang dikenal dengan keindahan alam dan budaya yang indah dan tentunya menawan. Ini pun dapat disampaikan dengan lebih baik lagi kepada wisatawan dengan kemampuan pramuwisata yang memiliki wawasan luas. Satu hal yang menjadi tolak ukur wawasan bagi para pramuwisata adalah pembangunan pariwisata di Bali memiliki orientasi menjadi pariwisata budaya (Karmini, Dyatmika,
Suasthi, Wardhani, \& Pradana, 2020). Wawasan inipun bukan hanya sekedar tempat wisata yang dikunjungi namun juga khazanah budaya lokal yang tentunya menjadi daya tarik wisatawan itu sendiri (Susila, Sudarmawan, \& Purandina, 2019). Gunawan dan Ariwangsa (2017) mengatakan bahwa pariwisata budaya atau cultural tourism merupakan situasi dimana wisatawan tersebut tidak hanya sekedar mengunjungi suatu tempat untuk menyaksikan dan menikmati atraksi, bisa saja mereka datang untuk mempelajari tentang keadaan budaya atau disebut dengan cultural tourism di tempat tersebut, pariwisata budaya ini juga memiliki peran penting dari semua jenis pariwisata yang ada di dunia (Irwan, Khadijah, Tahir, 2020). Pariwisata budaya ini tentunya akan menjadi salah satu daya tarik bagi wisatawan dikarenakan hal ini akan menjadi suat alternative bagi mereka dan tentunya menambah ilmu ketika mereka mengunjungi suatu tempat (Paramita \& Putra, 2020). Pendampingan kepada wisatawan inipun sangat penting yang dilakukan oleh para pramuwisata. Jika pendampingan tersebut disampaikan dengan baik maka wawasan yang didapatkan oleh wisatawan juga semakin baik dan mengesankan bagi mereka. Menurut Aristrawati (2018) salah satu cultural tourism yang dapat dinikmati oleh para wisatawan dengan pendampingan dari seorang pramuwisata adalah pengenalan cerita ogohogoh yang sering sekali menjadi pertanyaan bagi para wisatawan mengenai "apa itu ogohogoh?" "mengapa dibuat demikian?' "apa cerita dibaliknya?". Adanya ogoh-ogoh sebagai salah satu pariwisata budaya Bali merupakan salah satu daya tarik tidak hanya bagi warga domestik tetapi juga warga mancanegara yang sedang berlibur di Bali hal ini juga didukung dengan adanya pawai ogoh-ogoh yang tidak hanya dilakukan sehari sebelum hari raya Nyepi tetapi juga dilakukan secara komersil seperti: festival, promosi pariwisata, dan kegiatan pembukaan dalam event olahraga internasional (Prabandari \& Sonder, 2021). Dengan meningkatnya minat para wisatawan 
mancanegara dibutuhkan pramuwisata yang siap untuk menjelaskan segala sisi dan bentuk dari ogog-ogoh tersebut. Pendeskripsian ogoh-ogoh ini akan sangat membantu para wisatawan untuk memahami apa yang sebenarnya para pemuda pemudi atau warga Bali sampaikan dalam ogoh-ogoh yang memiliki berbagai macam rupa ini.

Berdasarkan pemaparan yang diberikan diatas, peneliti mencoba menemukan bagaimana tahap-tahap mengarjakan pendeskripsian ogoh-ogoh (teaching scenario) tersebut dilakukan dan tentunya pendeskripsian kepada para wisatawan ini dilakukan dengan bahasa Inggris untuk meningkatkan pemahaman serta minat para wisatawan saat berkunjung atau berlibur ke Bali dan tentunya demi keberlansungan pariwisata itu sendiri.

\section{METODE}

Penelitian ini bertujuan untuk menemukan tahapan pengajaran yang tepat untuk guiding dengan tema pariwisata budaya "Ogoh-Ogoh". Sebelum tahapan itu didapatkan, peneliti harus mengumpulkan terlebih dahulu deskripsi ogoh-ogoh berbahasa inggris sebagai materi pembelajaran. Data tersebut didapatkan dengan data kualitatif yang dipadukan dengan studi kepustakaan dalam menemukan teknik guidingnya. Data kualitatif dikumpulkan dengan cara observasi, dokumentasi, wawancara, dan tentunya studi kepustakaaan yang didapatkan dari berbagai sumber online. Instrumen penelitian adalah pedoman wawancara. Dalam menemukan informan untuk diwawancarai, peneliti menggunakan purposive sampling. Teknik analisis data adalah analisis data secara kualitatif dengan mendapatkan data secara serempak dan menjabarkan secara jelas data yang didapatkan melalui observasi, dokumentasi, dan wawancara atau biasa disebut dengan triangulasi data.

Menurut Sutopo (2016) triangulasi data dapat dilakukan dengan menggali informasi dari sumber-sumber data yang berbeda jenisnya, seperti narasumber tertentu, dari kondisi tertentu, dari aktivitas yang menggabarkan perilaku orang, atau dari sumber yang berupa catatan atau arsip dan dokumen. Dalam studi kepustakaan akan menjabarkan lebih cara teknik pengajaran guiding dengan tema pariwisata budaya "Ogoh-Ogoh". Hasil dari data tersebut dianalisis dengan cara reduksi data, klasifikasi data, display data, dan menarik kesimpulan

\section{HASIL DAN PEMBAHASAN}

Di bagian ini dijelaskan mengenai hasil dari observasi, wawancara, dan dokumentasi yang didapatkan setelah melakukan penelitian terhadap cerita ogoh-ogoh yang terdapat di Denpasar. Observasi dilakukan dengan mengunjungi beberapa arsitek ogohogoh. Arsitek-arsitek ini didapatkan dengan menanyakan kepada pemuda-pemudi yang ada di banjar tersebut. Observasi ini dilakukan untuk mendapatkan sumber yang tepat untuk mengetahui informan yang tepat untuk dilakukan wawancara. Beberapa arsitek ini selanjutnya akan disebut sebagai $\mathrm{X}, \mathrm{Y}$, dan Z. ketiga informan ini merupakan narasumber yang tepat karena sudah berpuluh-puluh tahun menjadi arsitek di banjar-banjar tersebut. Dari ketiga informan tersebut didapatkan hasil wawancara sebagai berikut:

1. Para arsitek ini sudah tinggal dari lahir di banjar tersebut.

2. Sudah Membuat ogoh-ogoh kurang lebih dari 5 tahun kebelakang

3. Tema yang sering diambil adalah sebagian besar berwujud hewan, raksasa, pengeleakan, dan terkadang menceritakan suatu pertempuran antara Dewa dengan raksasa, seperti dalam kisah Ramayana.

4. Tema diambil berdasarkan dari persetujuan terbanyak dari para pemuda dan disetujui oleh arsitek banjar tersebut

Setelah melakukan wawancara dengan para arsitek tersebut, peneliti meminta dokumentasi yang pernah dikumpulkan serta 
cerita dibalik pembuatan ogoh-ogoh tersebut. Ogoh-ogoh yang dibuat dengan tema raksasa salah satunya dengan tema "Bawi Srenggi". Bawi Srenggi, dari cerita yang dipaparkan oleh salah satu arsitek menyebutkan bahwa tema ini menceritakan raja raksasa berwujud celeng atau babi yang menyukai Dewi Sri, namun Dewi Sri menolak karena tlah bersuami dengan Dewa Wisnu. Kemudian Dewi Sri kabur ke Bumi dan menjadi tumbuh-tumbuhan. Hal inipun diketahui oleh Bawi Srenggi, kemudian ia ke Bumi dan mengobrak abrik persawahan demi mendapatkan Dewi Sri yang berwujud tanaman tersebut. Raja yang pada saat itu bernama Sri Aji Pangukuhan bertindak untuk menangani Bawi Srenggi dan pertempuran pun terjadi. Akhir cerita, Bawi Sranggi dikalahkan oleh Sri Aji Pangukuhan dan sebelum pergi, Bawi Srenggi memberikan kutukan apabila di suatu tempat muncul serangga (ulat) "lulut" itulah sebagai pertanda kedatangan Bawi Srenggi di tempat tersebut. Oleh sebab itu apabila di suatu tempat ditemukan serangga (ulat) "lulut" maka di tempat tersebut harus diadakan upacara pecaruan.

Adapun cerita tentang pengeleakan seperti siwa klakah, dimana cerita ini berdasar dari ilmu pengeleakan di Bali. Sudah dipercayai oleh banyak kalangan masyarakat, terutama masyarakat Bali bahwa dalam ilmu pengeleakan memiliki tingkatannya dan penceritaan ilmu pengeleakan "Siwa klakah" merupakan ilmu tertinggi dari ilmu pengeleakan yang dapat mengendalikan ke tujuh cahaya atau api yang ada dalam dirinya. Wujud dari seseorang yang dapat menguasai ajian Siwa Klakah ini sangat menyeramkan karena memiliki 5 kepala dengan berbagai wajah bhuta ajian pengeleakan lainnya serta memnunggangi wahana bersayap, sehingga setiap makhluk yang dilangkahi akan menemui ajalnya.

Cerita selanjutnya yang peneliti dapatkan adalah cerita tentang pertarungan epik Ramayana dimana cerita yang diambil lebih banyak dari raja raksasa Rahwana yang menculik sinta kemudian dikejar/diburu oleh pasukan monyet yang dipimpin oleh Hanoman. Cerita ini berawal dari raja raksasa yang mencintai satu wanita bernama Dewi Setyawati. Hingga kemudian sang dewi meninggal dan menitis menajdi Dewi Sinta. Waktu berlalu, kemudian Rahwana bertemu dengan Dewi Sinta yang sudah menjadi istri dari Rama. Rahwana pun tidak tinggal diam, oleh karena cintanya, ia menculik dan dibawa pulang ke Alengka. Selama tiga tahun disekap, Dewi Sinta diperlakukan bak ratu dan tidak pernah menyentuh wanita kesayangannya tersebut. Ia hanya menunggu agar sang dewi mencintainya sepenuh hati. Suatu saat nanti. Entah kapan. Walapun ia tahu bahwa Dewi Setyawati terlahir begitu setia pada suaminya. Rahwana yang dikenal dengan sangat ganas dan penuh amarah, menjadi berubah baik dan murah senyum dan membuat kerajaannya menjadi damai. Namun tibalah saatnya ia harus bertarung dengan Rama dikarenakan ia harus mendapatkan Sinta secara utuh, jika ia kalah maka Dewi Sinta akan kembali kepada rama. Singkat cerita, pertarungan pun terjadi, disinilah Rahwana dikalahkan oleh Rama dengan pasukan Hanomannya. Dari cerita inilah terbentuk ogoh-ogoh sedemikian rupa dengan tema pertarungan epik Rahwana yang menculik Dewi Sinta dan melawan berbagai pasukan monyet (Hanoman).

Setelah mendapatkan cerita dari ogohogoh yang diberikan oleh masing-masing arsitek. Peneliti kemudian menerjemahkan cerita tersebut ke dalam bahasa Inggris sehingga menjadi sebuah daya tarik sendiri bagi wisatawan yang berkunjung ke Bali.

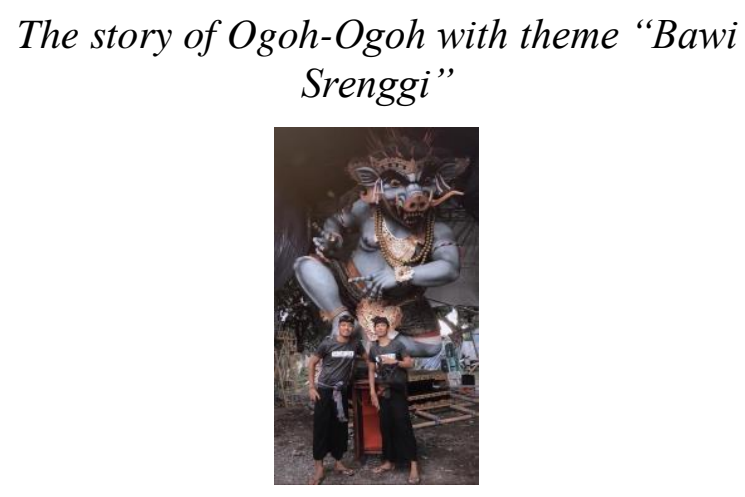

Gambar 1. Bawi Srenggi

(source: private document of the architect,2020) 
"Commonly, the form of Ogoh-Ogohs is a Giant or monster that has fangs, long nails, red eyes, and messy hair. One of them is Bawi Srenggi, Bawi means "Pig" so the form of this OgohOgoh is in Giant Pig and has the characteristics of monster. This Ogoh-Ogoh was based on the story of a king of monster called "Bawi Srenggi" who fell in love with a goddess called "Dewi Sri”. Unfortunately Dewi Sri was already married with Dewa Wisnu (Lord Vishnu). Then Dewi Sri escaped to Earth and became a plant after she arrived on the Earth. Heard by Bawi Srenggi, then he came to the Earth and tried to find Dewi Sri. With all of his strength, he destroyed all the rice field in order to find a plant that Dewi Sri became. The people around the rice field were scared and told this situation to their king, Sri Aji Pangukuhan. Sri Aji Pangukuhan came to the rice field and fight against Bawi Srenggi. Shortly, Bawi Srenggi was defeated by Sri Aji Pangkuhuan and before he died, he said that there would be a time when a worm with golden color appeared in a rice field in a village that was a sign of the appearance of Bawi Srenggi and he would come and destroy the field again, that's why if these worms appeared in Bali, there will be a ritual to neutralize the situation",

\section{"The Story of Ogoh-Ogoh with theme "Siwa Klakah"}

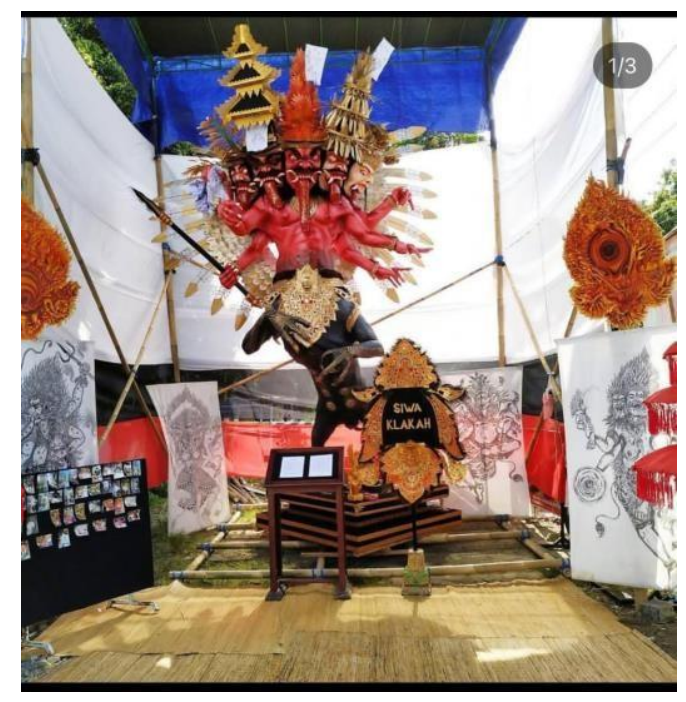

Gambar 2. Siwa Klakah

(source: Instagram of ST. Widyabhakti, 2019)

"It is commonly known that the form of OgohOgoh is Giant or Monster, sometimes the form of Ogoh-ogoh is also in the form of the stages of "Leak". Leak in Bali is known as magic knowledge and this magic knowledge has forms in every stages. One of the stages is called "Siwa Klakah". Siwa Klakah is known as the highest stage or final stage of "Leak" knowledge. This form has the ability to control all the light inside himself. The shapes of this form is quite scary. It has 5 faces with many expression and rides a flying things that make every creatures that are stepped over by Siwa Klakah will immediately die."

\section{"The Story of Ogoh-Ogoh with theme "Epic} Battle of Rama and Rahwana (Ramayana)"

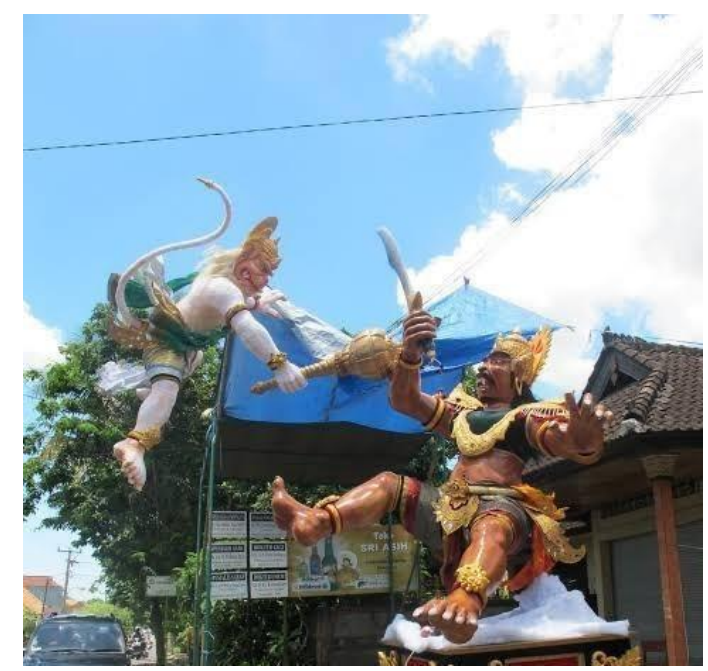

Gambar 3. Ramayana

(source: ferdiasbookelmann.wordpress.com, 2014)

"It is commonly known that the form of OgohOgoh is Giant or Monster and this form can also be taken from story that has figure of monster within the story. One of the epic story that has figure of monster is the Epic of Ramayana. As known that Ramayana has figure of monster called "Rahwana" and this figure commonly appears if someone wants to make Ogoh-Ogoh with theme "Ramayana" because he is the symbol of monster in this story. This epic battle was started from the willing of King of Monster "Rahwana" to marry with Dewi Sinta because Rahwana believed that Dewi Sinta is the incarnation of Dewi Setyawati -the woman he loved who died-. Unfortunately, Dewi Sinta had already married with Rama and this situation made Rahwana wanted to kidnap Dewi Sinta and made her the queen of his kingdom. Shortly, Rahwana successfully kidnapped Dewi Sinta and brought her to his kingdom. There, Dewi Sinta was treated like a queen and made Rahwana happy, but there was a time when he must fight against Rama in order to have Dewi Sinta all 
himself. Rama with the help from the army of monkeys and also its king "Hanoman" defeated Rahwana. Based on this situation, the form of Ogoh-Ogoh with theme "Ramayana" was made.

Setelah mendapatkan data cerita ogoh-ogoh dari para narasumber melalui wawancara. Peneliti, kemudian mencari sumber dari library research untuk menemukan tahapan tour guide yang tepat untuk dilakukan di dalam kelas atau lebih tepatnya di bagian mana materi pramuwisata tentang ogoh ogoh ini ditempatkan di Rencana Pelaksanaan Pembelajaran. Berdasarkan hasil evaluasi dari berbagai sumber yang didapatkan, peneliti menemukan bahwa dalam pembelajaran tour guide memiliki banyak teknik. Menurut Susila, Sudarmawan, dan Purandina (2019) terdapat 7 teknik dalam pembelajaran tourguide yaitu: 1) Role-play (Melakukan peran) 2) Brainstorming (Bertukar Pikiran),

3) Storytelling (Bercerita), 4) Interview (Wawancara), 5) Reporting (Laporan), 6) Picture Describing (mendeskripsikan Gambar), 7) Find The Difference (Menemukan Perbedaan).

Tidak dapat dipungkiri bahwa 7 teknik diatas memiliki kekurangan dan kelebihannya ketika digunakan di dalam kelas. Ketujuh teknik itupun kemudian dianalisis dari berbagai sumber untuk menemukan teknik yang tepat dalam pengajaran tour guide dengan materi "cerita ogoh-ogoh sebagai pengenalan pariwisata budaya kepada wisatawan". Penelitipun melakukan wawancara kepada pengajar tour guide untuk menemukan teknik mana yang tepat. Setelah melakukan wawancara kepada pengajar tour guide, ditemukanlah bahwa teknik yang tepat untuk materi ini adalah teknik story telling yang kemudian akan disebutkan sebagai teknik bercerita. Teknik bercerita dikatakan sebagai teknik yang tepat dikarenakan teknik ini, umumnya disukai oleh pendengar karena mempunyai pengaruh yang bagus kemudian membuat para pendengar mengingat atau membayangkan sebuah kisah dengan cepat dan tepat.
Menurut Pratiwi (2016) Bercerita merupakan suatu kegiatan yang dilakukan secara lisan kepada pendengar dengan alat tertentu yang berbentuk sebuah pesan atau cerita dengan tujuan untuk memberikan informasi detail dan tentunya dapat didengarkan dengan rasa menyenangkan. Pratiwi (2016) juga menambahkan bahwa Bercerita mampu meningkatkan kemampuan berbicara para siswa karena 1) teknik ini memberikan pengalaman psikologis dan lingusitik sesuai minat mereka, tingkat perkembangan dan kebutuh mereka sekaligus kegiatan yang menyenangkan bagi mereka 2) Bercerita mampu mengembangkan potensi kemampuan berbahasa melalui mendengarkan maupun membaca kemudian menuturkannya kembali kepada pendengar dengan tujuan melatih keterampilan para siswa dalam bercakap-cakap dan mampu menyampaikan ide dalam bentuk lisan 3) Bercerita merupakan suatu kegiatana yang tidak membosankan dan menyenangkan saat dilakukan di kelas, 4) Bercerita memberikan informasi dan pengalaman yang menarik.

Setelah mengetahui teknik yang tepat, peneliti melakukan pencarian mengenai bagaimana teknik ini dapat dilakukan di kelas dan tentunya dengan materi "cerita ogoh-ogoh sebagai pengenalan pariwisata budaya kepada wisatawan". Peneliti melihat berbagai RPP yang kemudian dapat dikombinasikan dengan materi tersebut. Setelah menukam RPP yang tepat, peneliti menemukan bahwa teknik dapat dikombinaksikan dengan materi di atas yang terdapat pada tahapan ke-4 atau tahapan bercerita. Tahapan pembelajaran tersebut dapat dijabarkan sebagai berikut (Pratiwi, 2016):

1. Memilih tema dan judul cerita yang akan dibawakan yaitu "cerita ogohogoh sebagai pengenalan pariwisata budaya kepada wisatawan"

2. Menkondisikan para siswa

3. Tahapan membuka atau mengawali mencakup kegiatan: 
a. Menanyakan kesiapan untuk mendengarkan cerita.

b. Menyampaikan materi atau isi cerita secara singkat.

c. Memberikan informasi tentang tokoh-tokoh yang akan muncul dalam cerita.

d. Meminta siswa membaca materi tersebut dengan menggambarkan tempat, menggambarkan waktu, ekspresi emosi yang ada dalam cerita tersebut.

4. Tahapan saat bercerita mencakup kegiatan:

a. Memotivasi para siswa untuk mampu menceritakan kisah tersebut di depan kelas dengan ekspresi mereka sendiri.

b. Memantau para siswa yang maju ke depan kelas dengan memberikan pertanyaan-pertanyaan umum (sebagai wisatawan) untuk memperdalam pemahaman cerita.

c. Memberi kesempatan untuk menginterpretasi cerita.

d. Menterjemahkan kata-kata yang masih dirasa sulit diterima oleh anak.

5. Tahapan menutup cerita dan evaluasi

a. Tanya jawab (diskusi) seputar tokoh-tokoh dan perbuatan yang harus dincontoh dan ditinggalkan.

b. Mendorong siswa untuk mencoba menceritakan kembali atau bercerita dengan kreasi sendiri dan memberikan reward kepada siswa yang mau bercerita.

Kelima tahapan diatas sudah mencangkup pendahuluan, isi, dan penutup dari sebuah RPP. Penceritaan ogoh-ogohpun dapat dikondisikan dengan membuat para pengajar untuk berpura-pura menjadi wisatawan (bermain peran) dengan tujuan membuat para siswa mendapatkan pengalaman yang autektik secara tidak langsung walaupun masih dalam konteks kelas. Para siswpun diminta untuk mampu menginterprestasikan cerita yang mereka sampaikan sehingga mereka mengetahui cerita mereka secara menyeluruh tidak hanya per kalimat saja.

\section{SIMPULAN}

Pengajaran tour guide tentu menjadi sebuah pembelajaran yang sangat penting dalam dunia pariwisata karena menjadi pramuwisata merupakan seseorang yang menjadi infroman bagi pariwisata apabila para wisatawan memiliki ketertarikan akan suatu hal namun tidak mengerti secara detail hal tersebut dikarenakan memiliki budaya yang berbeda. Salah satu ketertarikan yang dimiliki para wisatawan dalam konteks pariwisata budaya adalah adanya pengarakan ogoh-ogoh yang dilakukan sehari sebelum Hari Raya Nyepi di Bali. Adanya ogoh-ogoh ini tidak lepas dari cerita yang disampaikan dibaliknya. Cerita ogoh-ogoh inipun menjadi suatu ketertarikan tersendiri bagi kalangan wisatawan dikarenakan bentuk dan rupa ogoh-ogoh sedemikian rupa yang memiliki simbol dimasing-masing lekukannya. Untuk membuat calon pramuwisata mampu menceritakan dengan baik cerita ogoh-ogoh tersebut diperlukan suatu teknik yang tepat supaya mereka dapat mempraktekkannya di dunia kerja nanti.

Salah satu teknik yang dapat diterapkan oleh para pengajar tour guide adalah story telling (Bercerita). Teknik secara umum merupakan suatu teknik yang dilakukan secara lisan untuk memberikan suatu detail informasi kepada pendengar. Bercerita memiliki kelebihan dalam mengembangkan kemampuan berbicara para siswa dikarenakan teknik mengembangkan kemampuan linguistic mereka dan tentunya membantu mereka untuk meningkatkan penyampaian ide secara lisan. Para pengajarpun harus menemukan tahap-tahap pengajaran yang tepat untuk dapat mengaplikasikan teknik ini di kelas. Tahapan dalam mengajarkan cerita ogoh-ogoh sebagai pengenalan pariwisata budaya kepada wisatawan terdapat 5 tahapan yang dimana tahap pertama berfokus pada pencarian cerita 
ogoh-ogoh yang menarik dan tentunya menyenangkan untuk dapat diceritakan. Tahapan kedua berfokus pada kesiapan para siswa dengan memberikan pancingan yang terkait dengan materi. Tahapan ketiga memberikan gambaran kepada para siswa tentang cerita ogoh-ogoh tersebut dan meminta mereka berlatih dengan ekspresi mereka sendiri dalam bercerita. Tahapan keempat berfokus pada bagaimana cara mereka menjadi pramuwisata dengan penejelasan cerita ogoh-ogoh yang mereka bawakan dan tentunya tahapan inilah yang paling penting ketika memberikan pembelajaran tour guide. Tahapan kelima hanya berfokus pada pemberian umpan balik dengan tujuan menambah pengetahuan yang mereka dapat sebelumnya.

\section{UCAPAN TERIMA KASIH}

Pada sesi ini, peneliti megucapkan terima kasih yang sebanyak-banyaknya kepada para narasumber yang sudah membantu pencarian data dan menyambut baik penelitian ini. Tidak lupa juga peneliti mengucapkan terima kasih kepada para pengajar mata pelajaran tour guide yang sudah meluangkan waktunya untuk memberikan informasi mengenai teknik yang tepat untuk dilakukan dengan materi "Cerita Ogoh-Ogoh Sebagai Pengenalan Pariwisata Budaya Kepada Wisatawan".

\section{REFERENSI}

Aristrawati, N. P. (2018). Evaluasi Parade "OGOH-OGOH" Sebagai Pendukung Pengembangan Pariwisata Budaya di Kota Denpasar. Jurnal Master Pariwisata (JUMPA), 5(1), 147-170.

Gunawan, I. D., \& Ariwangsa, I. B. (2017). Potensi The Ogoh-Ogoh Bali Collection Sebagai Atraksi Wisata Budaya Di Desa Mengwi Kabupaten Badung. Jurnal Destinasi Pariwisata, 5(1), 28-33.

Irwan, I., Khadijah, U. L., \& Tahir, R. (2020). Memperkenalkan Pariwisata
Budaya dan Heritage Kepada Generasi Muda Melalui Virtual Tour ke Pulau Penyengat. Sosial Budaya, 17(2), 133-140.

Karmini, N. W., Dyatmikawati, N. P., Suasthi, G. A., Wardhani, N. K., \& Pradana, G. K. (2020). Objek wisata pura Tirta Empul sebagai media pendidikan multikultural bagi generasi milenial pada era 4.0. Ganaya: Jurnal Ilmu Sosial Dan Humaniora, 2(3), 21-29.

Paramita, I. G., \& Putra, I. A. (2020). New Normal Bagi Pariwisata Bali Di Masa Pandemi Covid 19. Pariwisata Budaya: Jurnal Ilmiah Agama Dan Budaya, 5(2), 57-65.

Pebriana, F., Mulyawan, R., \& Sutrisno, B. (2021). Strategi Pemerintah Daerah dalam Pengembangan Pariwisata untuk Meningkatkan Pendapatan Asli Daerah. Janitra (Jurnal Administrasi Pemerintahan), 1(1), 11-22.

Prabandari, I. S., \& Sonder, I. W. (2021). Dampak Pawai Ogoh-ogoh Terhadap Sosial Budaya Masyarakat di Desa Adat Kuta. Pariwisata Budaya: Jurnal Ilmiah Agama dan Budaya, 6(1), 92-103.

Pratiwi, R. R. (2016). Penerapan Metode Storytelling Untuk Meningkatkan Keterampilan Berbicara Siswa Kelas II SDN S4 Bandung. Jurnal Pendidikan Guru Sekolah Dasar, 1(1), 199-207.

Susila, I. D., Sudarmawan, I. Y., \& Purandina, I. Y. (2019). Teknik Pengajaran English for Guiding Berbasis Etnopedagogi. Seminar Nasional Inovasi dalam Penelitian Sains, Teknologi dan HumanioraInoBali (pp. 341-346). Denpasar: Teknologi dan Humaniora-InoBali. 


\section{BIODATA PENULIS}

Md. Yudyantara Risadi, ia lahir di Denpasar di akhir tahun 1995 dan menempuh pendidkan dari SD hingga SMA di sekolah Negeri yang ada di Kota Denpasar. Yudyantara atau yang akrab dipanggil Yudik ini menyelesaikan Program S1 dan S2 di Universitas Pendidikan Ganesha, Singaraja dengan program studi Pendidikan Bahasa Inggris. Setelah menyelesaikan perkuliahannya, Yudik menjalani karir dosen yang dimulai dari mengajar kampus perhotelan serta kampus penerbangan. Dilanjutkan menjadi dosen yayasan di suatu kampus perhotelan yaitu AKPAR DENPASAR. Di kampus ini Yudyantara menjalani banyak pengalaman yang berkaitan dengan Tri Dharma Perguruan Tinggi. Dalam karya ilmiah, yudik sudah menulis beberapa tulisan yang tentunya sudah dipublikasikan baik nasional ataupun internasional. Setelah menjalani karir yang cukup panjang untuk saat ini Yudyantara bekerja sebagai Dosen CPNS 2019 di Universitas Hindu Negeri I Gusti Bagus Sugriwa. 